\title{
Do the ISO 14001 Environmental Management Systems Influence Eco-innovation Performance? Evidences from the EU Context.
}

\author{
Stefano Brogi ${ }^{a, b^{*}}$, Tamara Menichini ${ }^{a}$
}

\begin{abstract}
Eco-innovation has become a clear target of EU policy strategies. Consequently, detecting drivers of eco-innovation has become crucial to design effective eco-innovation policies. The paper focuses on the adoption of ISO 14001 standard, with the aim to investigate to what extent the ISO certification of Environmental Management Systems influences eco-innovation performance. A correlation analysis between data from European Eco-Innovation Scoreboard interactive tool (ECOIS) reveals that, at EU country level, there is no a significant correlation between the number of ISO 14001 certified organizations and the level of some selected Eco-Innovation performance indicators. Both the number of companies that have developed innovations with environmental benefits and the number of patents in environmentally-related technologies are not significantly related to the number of companies with ISO 14001 certification. Similar results were obtained by considering only Eco-Innovation leaders, that is EU countries with above-average Eco-Innovation Index values. These empirical evidences arise some questions and policy suggestions that will be discussed.
\end{abstract}

Keywords: Eco-innovation drivers; Environmental Management Systems; ISO 14001 certification; Eco-Innovation Scoreboard; Eco-Innovation Index.

\section{Introduction}

Innovation is the implementation of a new or significantly improved product, process, marketing technique or organizational method (OECD, 2005). Eco-innovation is "any form of innovation aiming at significant and demonstrable progress towards the goal of sustainable development, through reducing impacts on the environment or achieving a more efficient and responsible use of natural resources" (Decision $\mathrm{N}^{\circ}$ 1639/2006/EC, L. 310-17). In December 2011, the European Commission adopted the Eco-innovation Action Plan (EcoAP) with the aim of green innovations' diffusion by tackling its barriers and drivers. Eco-innovation has therefore become an explicit target of European Union (EU) policy strategies, enabling the transition to a green economy, a fundamental factor in order to recover from the current economic recession (Marin et al., 2015).

Consequently, measuring eco-innovation performance at EU country level has become crucial to detect eco-innovation patterns and to design eco-innovation policy implementation. The Eco-innovation index, used by the EU as an information tool for EcoAP (Park et al., 2017), through 16 indicators monitored by of the Eco-Innovation

\footnotetext{
andustrial and Mechanical Engineering University of Rome "Niccolò Cusano" Via Don C. Gnocchi, 3.

bItalian National Research Council (CNR) - Piazzale Aldo Moro, 7 - 00185 Rome, Italy.
} 
Scoreboard (ECO-IS), helps policy makers to understand, nation by nation, overall ecoinnovation performance tracing its inputs and outputs.

Determinants of eco-innovation have been widely explored by the literature (Horbach, 2008; Montalvo, 2008; Kesidou \& Demirel, 2012; Horbach et al., 2012; Marin et al., 2015; Bossle et al., 2016), which has recognized the crucial role of institutional side (e.g. regulatory environmental institutional policy), supply side (e.g. firms' technological and organizational capabilities), demand side (e.g. social awareness and environmental consciousness towards green products) as factors in affecting the development of green innovations. Most literature recognizes regulation as the most important driver of ecoinnovation (Porter \& van der Linde, 1995; Kammerer, 2009; Doran \& Ryan, 2012).

Regulation strategies include command and control regulations, self-regulation, incentive-based schemes, market exploitation controls, disclosure regulation, direct actions and public compensation mechanisms (Baldwin \& Cave, 1999). Since the market alone fails to deliver results of public interest (Dewing \& Russell, 2004) environmental regulations are very useful to support a greener environment by specifying policies and providing strict guidelines to polluters and eco-innovators, thanks to their informative and normative nature (Kemp, 2000).

Over the past two decades, governments and industry lobby groups have promoted proactive voluntary approaches to normative and social public pressure, in order to deal with more stringent environmental regulations (Barla, 2007). The implementation of Environmental Management Systems (EMSs) that are voluntary self-regulation frameworks setting procedures and management rules used to reduce the organization's impact on the environment (Darnall, 2006), is considered an internal organizational driver to trigger the adoption of eco-innovation (Rennings et al., 2006; Wagner, 2007; Horbach, 2008; Demirel \& Kesidou, 2001; Bossle at al., 2016). Unlike government regulation that imposes requirements on firms from outside, EMSs create environmental awareness within organizations (Darnall \& Edwards, 2006; Rehfeld et al., 2007) and favor the development of eco-innovations (Rehfeld et al., 2007). Therefore, the adoption of voluntary schemes as EMS could anticipate more stringent environmental normative (Kollman \& Prakash, 2002).

Among the existing schemes for EMS, the International Organization for Standardization (ISO) 14001, which supports the improvement of environmental performance of companies, especially for those considered to be notably polluting, has become the most adopted standard for EMS implementation worldwide (HerasSaizarbitora, 2015). Since the official launch of ISO 14001 in 1996, about 360.000 organizations worldwide have obtained the certification; in Europe, from 7.253 certified firms in 2000 to 109.133 in 2017 (ISO, 2017). According to the ISO 14001 standard, an EMS is "the part of the overall management system that includes organizational structure, planning activities, responsibilities, practices, procedures, processes and resources for developing, implementing, achieving, reviewing, and maintaining the environmental policy" (ISO, 2006, Article 3). ISO 14001 standard entails a systematic voluntary process which leads to establish organization's environmental policies and to environmental regulatory compliance by draw-up measurable environmental targets and performing a continual review on their effectiveness (Salim et al., 2018). The framework needs investigation and certification by third-party entities (Kesidou \& Demirel, 2012). 
EMSs certified as ISO 14001, are fundamental means to guide and support both public environmental policies and sustainable commercial strategies of companies (Arimura et al., 2008). The main companies' benefits in adopting ISO 14001 standard are the improvement of the production efficiency, the compliance with environmental normative and the corporate reputation enhancement (Ferron-Vilkez, 2017; Mazzi et al., 2016; Oliveira et al., 2016; Prajogo et al., 2012). Furthermore, among the EMS certifications, only the implementation of the ISO 14001 standard becomes an important eco-innovation driver both in the development and in the adoption-diffusion phase (Hojnik \& Ruzzier, 2016).

However, the EMS certification is also surrounded by criticism due to its high implementation costs and due to the fact that for some companies the certification is exclusively a bureaucratic fulfillment not linked to an effective commitment to improve environmental impacts (Curkovic \& Sroufe, 2011 ; Ferron-Vilchez, 2017).

Since the environmental objectives are established internally by the management of the company, and not by the standard, the implementation of ISO 14001, which is rather process-oriented, is not necessarily associated with an improvement in performance towards the environment (Barla, 2007; Prajogo et al., 2012; Mazzi et al., 2016; Li \& Hamblin, 2016).

Based on the previous arguments, the research question of this study is to investigate to what extent the ISO 14001 certification influences eco-innovation performance. This study shows evidences from the EU context drawing on data from the aforementioned on-line interactive tool ECO-IS.

The rest of the paper is structured as follows. The next section summarizes the background concerning the ISO 14001 standard and the ECO-IS. Section 3 illustrates data and method. Section 4 describes the results. Section 5 concludes discussing the results and suggesting some policy implications.

\section{Backgrounds}

\subsection{ISO 14001 standard}

ISO 14001 is the most widespread international standard that provides companies with a basic framework in order to develop and maintain an effective EMS. ISO 14001 standard was approved in 1996 in a brief document entitled "Environmental management system - Specification with guidance for use" by a non-governmental International Organization for Standardization (ISO), located in Geneva. The ISO 14001 standard was revised in 2004 and in 2015 and, together with a set of other guidelines, constitutes the ISO 14000 series. However, ISO 14001 is the only standard that specifies EMS requirements in the ISO 14000 series. For this reason, an organization can be certified only against this standard by an accredited third-party entity (Curkovic \& Sroufe, 2011). ISO 14001 requirements define a model by means of which any type of organization, regardless of size, sector or geographical location, can implement a management framework to improve its overall environmental performance with a systematic virtuous approach (ISO, 2015). It is important to note that ISO 14001 is a process-oriented standard, so the proposed framework does not establish the level of environmental performance the firm must achieve nor a maturity model for 
environmental procedures and control indicators (Barla, 2007, Curkovic \& Sroufe, 2011; Oliveira et al., 2016). ISO 14001 outlines five basic requirements to set up an effective EMS: defining a corporate environmental policy and commitment to implement an EMS, drawing up a plan for its implementation, carrying out the EMS, monitoring and implementation of eventual corrective actions, periodically reviewing the EMS operations by top management to ensure continuous improvement of their effectiveness (Barla, 2007, Curkovic \& Sroufe, 2011).

Empirical studies reported that the implementation of a EMS has a positive impact upon eco-innovation (Wagner, 2007; Horback 2008; Kesidou \& Demirel, 2012; Hojinik \& Ruzzier, 2016). However, even though the implementation of ISO 14001 testifies the developing of organisational capabilities, management literature on EMS has shown that merely external certification does not enhance environmental innovation (Boiral, 2007; Rondinelli \& Vastag, 2000; Kesidou \& Demirel, 2012).

\subsection{ECO-IS}

The Eco-Innovation Scoreboard (ECO-IS) ${ }^{1}$ developed by the $\mathrm{EIO}^{2}$ is an online tool to trace and measure eco-innovation performance across the 28 EU Member States. The ECO-IS collects data starting from 2010 that allow monitoring how well each EU country performs in different dimensions of eco-innovation, compared to the EU average. As mentioned above, the scoreboard comprises 16 indicators grouped into five main categories that present a holistic view on economic, environmental and social EU countries' performance. The category "Eco-innovation Inputs" which comprises investments (financial or human resources) aiming at triggering eco-innovation activities, includes the following indicators: (1.1) "Governments environmental and energy R\&D appropriations and outlays"; (1.2) "Total R\&D personnel and researchers" and (1.3) "Total value of green early stage investments". The category "Eco-innovation Activities" category consists of three indicators representing innovative activities carried out by enterprises: (2.1) "Enterprises that introduced an innovation with environmental benefits obtained within the enterprise"; (2.2) "Enterprises that introduced an innovation with environmental benefits obtained by the end user" and (2.3) "ISO 14001 registered organizations". The category "Eco-innovation Outputs" representing the level of advancement and implementation of eco-innovation, includes: (3.1) "Eco-innovation related patents"; (3.2) "Eco-innovation related academic publications" and (3.3) "Ecoinnovation related media coverage". The category "Resource efficiency Outcomes" relating to wider effects of eco-innovation of improved resource productivity, includes: (4.1) "Material productivity"; (4.2) "Water productivity"; (4.3) "Energy productivity" and (4.4) "Greenhouse gas emissions intensity". The category "Socio-Economic Outcomes", which represents wider effects of eco-innovation activities for society and the economy, embraces three indicators relating to eco-industry area: (5.1) "Exports of products from

1 Available at https://ec.europa.eu/environment/ecoap/indicators/index_en

2 The Eco-Innovation Observatory (EIO) is an initiative financed by the European Commission's DirectorateGeneral for the Environment from the Competitiveness and Innovation framework Programme (CIP). The Observatory functions as a platform for the structured collection and analysis of an extensive range of eco-innovation integrated information, targeting business, policy makers, researchers and analysts. 
eco-industries"; (5.2) "Employment in eco-industries and circular economy" and (5.3) "Revenue in eco-industries and circular economy".

Half of the indicators are measured with statistical data of EUROSTAT, the EU statistical office while the rest are calculated by means of open data from international organization, such as Patstat, Water Footprint Network and Scopus (Park et al., 2017). ECO-IS is not a static tool because it is continuously adapted and improved, as new data sources become available (Giljum at al., 2018a). Country specific figures of the single indicator are weighted with the share of population in order to calculate an EU average that corrects the bias of smaller countries, consequently each indicator is re-scaled to EU average settled at 100 . The higher is the indicator value, the higher is the ecoperformance. The overall ECO Innovation Index of each EU member state is calculated by the unweighted mean of the 16 sub-indicators in order to avoid bias between the five thematic areas of the index and then it is scaled to the reference EU average settled at 100. This setting facilitates index understanding and comparison between countries. Countries with higher values than the EU average, obtain a higher score than 100 and countries with lower figures achieve less, depending on the deviation from the EU average. Therefore, countries are grouped into three clusters (Giljum et al., 2018b): "Eco-innovation leaders", scoring significantly higher than the EU average (i.e. a score $>115$ ); “Average eco-innovation performers' with scores around the EU average (i.e. between 85 and 115); "Countries catching up in eco-innovation" with around 85\% or less performance compared to the EU average (i.e. scores <85).

\section{Data and Method}

This study used data collected from the on-line ECO-IS database. As described in the previous section, the available data are not raw data, rather rescaled data in order to make the various EU countries comparable for each performance indicator related to eco-innovation. Considering the relevance of observing environmental management requirements for business, as a proxy for the level of environmental awareness and management capability, the on-line ECO-IS tool makes available the number per million of population of ISO 14001 registered organizations (ECO-IS indicator 2.3) for each EU country. Starting from that indicator we selected three more indicators for evaluate the eco-innovation's activity of firms for each country. Precisely, the percentage of enterprises that introduced an innovation with environmental benefits obtained within the firm (ECO-IS indicator 2.1), the percentage of enterprises that introduced an innovation with environmental benefits obtained by the end user (ECO-IS indicator 2.2) and the number, per million of population, of eco-innovation related patents ${ }^{3}$ (ECO-IS indicator 3.1).

In order to address the research question, we performed a correlation analysis between the ECO-IS indicator 2.3 and each of the other indicators mentioned above, using the Spearman rank correlation coefficient as proposed by Gauthier (2001). This nonparametric correlation technique operates on ranks of the data rather than on raw data, it

\footnotetext{
3 Main environmentally-related technologies involved: energy generation from renewable and non-fossil sources, combustion technologies with mitigation potential, emissions abatement and fuel efficiency in transportation, energy efficiency in buildings and lighting (Giljum at al., 2018a).
} 
is unaffected by the distribution of the population, it is quite insensitive to outliers and it is relatively simple to apply (Gauthier, 2001). We set up the analysis on the EU countries for which the ECO-IS makes available the data for the years 2015-2016-2017, then we focused on the "Eco-innovation leaders" cluster.

\section{Results}

The results of this study are presented as follows. For brevity, the detailed values of correlation analysis are reported only for the year 2017. Table 1 shows Spearman technique's dataset for year 2017 in which $\mathrm{X}$ variable stands for value of ECO-IS indicator (2.3) "ISO 14001 registered organizations" and Y variable stands for value of ECO-IS indicator (2.1) "Enterprises that introduced an innovation with environmental benefits obtained within the firm". For the year 2017 only 20 countries have available data for the both selected indicators. As the data pairs $n=20$ and the sum of squared difference between ranks is 1691.5, the Spearman rank correlation coefficient (Rs) is equal to -0.272 . The absolute value of Rs is smaller than the critical value Rc (equal to 0.380 for $\mathrm{n}=20$ and $\alpha=0.05)$. Therefore, the obtained Spearman rank correlation coefficient is not significant at the $95 \%$ probability level.

Table 1: Spearman rank correlation dataset between ECO-IS indicator 2.3 and ECO-IS indicator

2.1 for the year 2017

\begin{tabular}{|l|r|r|r|r|r|r|}
\hline & $\mathbf{X}=\mathbf{2 . 3}$ & $\mathbf{Y}=\mathbf{2 . 1}$ & RANK X & RANK Y & $\mathbf{d}$ & $\mathbf{d}^{\wedge} \mathbf{2}$ \\
\hline Austria & 41 & 152 & 4 & 19 & 15 & 225 \\
\hline Bulgaria & 127 & 10 & 13 & 1 & -12 & 144 \\
\hline Croatia & 112 & 77 & 12 & 9 & -3 & 9 \\
\hline Czech Republic & 230 & 84 & 17 & 10 & -7 & 49 \\
\hline Denmark & 79 & 49 & 8 & 7 & -1 & 1 \\
\hline Estonia & 205 & 34 & 16 & 5 & -11 & 121 \\
\hline Finland & 130 & 128 & 14 & 16,5 & 2,5 & 6,25 \\
\hline Germany & 25 & 188 & 2 & 20 & 18 & 324 \\
\hline Greece & 31 & 92 & 3 & 13 & 10 & 100 \\
\hline Hungary & 107 & 27 & 10 & 3 & -7 & 49 \\
\hline Italy & 261 & 90 & 19 & 12 & -7 & 49 \\
\hline Latvia & 56 & 33 & 7 & 4 & -3 & 9 \\
\hline Lithuania & 110 & 88 & 11 & 11 & 0 & 0 \\
\hline Luxembourg & 51 & 128 & 6 & 16,5 & 10,5 & 110,25 \\
\hline Malta & 330 & 51 & 20 & 8 & -12 & 144 \\
\hline Poland & 3 & 18 & 1 & 2 & 1 & 1 \\
\hline Portugal & 45 & 149 & 5 & 18 & 13 & 169 \\
\hline Slovakia & 252 & 43 & 18 & 6 & -12 & 144 \\
\hline Slovenia & 104 & 113 & 9 & 15 & 6 & 36 \\
\hline Sweden & 146 & 112 & 15 & 14 & -1 & 1 \\
\hline
\end{tabular}

Table 2 shows the dataset for the same year 2017 and for the same $\mathrm{X}$ variable (value of ECO-IS indicator 2.3) compared to Y' variable that stands for value of ECO-IS indicator 
(2.2) "Enterprises that introduced an innovation with environmental benefits obtained by the end user". Also, in this case only 20 countries have available data for the both selected indicators. As $n=20$ and the sum of squared difference between ranks is 1657.5, the Spearman rank correlation coefficient (Rs) is equal to -0.246 . The absolute value of $R s$ is smaller than the critical value Rc (equal to 0.380 for $n=20$ and $\alpha=0.05$ ). Therefore, the obtained Spearman rank correlation coefficient is not significant at the $95 \%$ probability level.

Table 2: Spearman rank correlation dataset between ECO-IS indicator 2.3 and ECO-IS indicator 2.2 for the year 2017.

\begin{tabular}{|l|r|r|r|r|r|r|}
\cline { 2 - 7 } & $\mathbf{X}=\mathbf{2 . 3}$ & $\mathbf{Y}^{\prime}=\mathbf{2 . 2}$ & RANK X & RANK Y & $\mathbf{d}$ & $\mathbf{d}^{\wedge} \mathbf{2}$ \\
\hline Austria & 41 & 193 & 4 & 19 & 15 & 225 \\
\hline Bulgaria & 127 & 12 & 13 & 1 & -12 & 144 \\
\hline Croatia & 112 & 98 & 12 & 11 & -1 & 1 \\
\hline Czech Republic & 230 & 108 & 17 & 12 & -5 & 25 \\
\hline Denmark & 79 & 57 & 8 & 8,5 & 0,5 & 0,25 \\
\hline Estonia & 205 & 42 & 16 & 5 & -11 & 121 \\
\hline Finland & 130 & 198 & 14 & 20 & 6 & 36 \\
\hline Germany & 25 & 189 & 2 & 18 & 16 & 256 \\
\hline Greece & 31 & 139 & 3 & 13 & 10 & 100 \\
\hline Hungary & 107 & 32 & 10 & 3 & -7 & 49 \\
\hline Italy & 261 & 44 & 19 & 7 & -12 & 144 \\
\hline Latvia & 56 & 41 & 7 & 4 & -3 & 9 \\
\hline Lithuania & 110 & 92 & 11 & 10 & -1 & 1 \\
\hline Luxembourg & 51 & 163 & 6 & 16 & 10 & 100 \\
\hline Malta & 330 & 57 & 20 & 8,5 & $-11,5$ & 132,25 \\
\hline Poland & 3 & 25 & 1 & 2 & 1 & 1 \\
\hline Portugal & 45 & 171 & 5 & 17 & 12 & 144 \\
\hline Slovakia & 252 & 43 & 18 & 6 & -12 & 144 \\
\hline Slovenia & 104 & 148 & 9 & 14 & 5 & 25 \\
\hline Sweden & 146 & 158 & 15 & 15 & 0 & 0 \\
\hline
\end{tabular}

Similarly, Table 3 shows the dataset for the same year 2017 and for the same X variable (value of ECO-IS indicator 2.3) compared to Y" variable that stands for value of ECOIS indicator (3.1) "Eco-innovation related patents". In this case 25 countries have available data for the both selected indicators. As $n=25$ and the sum of squared difference between ranks is 3264.5, the Spearman rank correlation coefficient (Rs) is equal to -0.256 . The absolute value of Rs is smaller than the critical value Rc (equal to 0.337 for $n=25$ and $\alpha=0.05)$. Therefore, the obtained Spearman rank correlation coefficient is not significant at the $95 \%$ probability level. 
Table 3: Spearman rank correlation dataset between ECO-IS indicator 2.3 and ECO-IS indicator 3.1 for the year 2017 .

\begin{tabular}{|l|r|r|r|r|r|r|}
\cline { 2 - 7 } & $\mathbf{X}=\mathbf{2 . 3}$ & $\mathbf{Y}^{\prime \prime}=\mathbf{3 . 1}$ & RANK X & RANK Y & $\mathbf{d}$ & $\mathbf{d}^{\wedge} \mathbf{2}$ \\
\hline Austria & 41 & 165 & 6 & 20 & 14 & 196 \\
\hline Belgium & 17 & 42 & 3 & 10 & 7 & 49 \\
\hline Bulgaria & 127 & 4 & 16 & 1 & -15 & 225 \\
\hline Croatia & 112 & 8 & 15 & 3 & -12 & 144 \\
\hline Czech Republic & 230 & 51 & 23 & 12,5 & $-10,5$ & 110,25 \\
\hline Denmark & 79 & 189 & 11 & 22 & 11 & 121 \\
\hline Estonia & 205 & 57 & 22 & 14 & -8 & 64 \\
\hline Finland & 130 & 228 & 18 & 23 & 5 & 25 \\
\hline France & 15 & 181 & 2 & 21 & 19 & 361 \\
\hline Germany & 25 & 235 & 4 & 24,5 & 20,5 & 420,25 \\
\hline Greece & 31 & 24 & 5 & 7 & 2 & 4 \\
\hline Ireland & 85 & 51 & 12 & 12,5 & 0,5 & 0,25 \\
\hline Italy & 261 & 14 & 25 & 5 & -20 & 400 \\
\hline Latvia & 56 & 26 & 9,5 & 8 & $-1,5$ & 2,25 \\
\hline Lithuania & 110 & 16 & 14 & 6 & -8 & 64 \\
\hline Luxembourg & 51 & 123 & 8 & 19 & 11 & 121 \\
\hline Netherlands & 56 & 83 & 9,5 & 18 & 8,5 & 72,25 \\
\hline Poland & 3 & 62 & 1 & 15 & 14 & 196 \\
\hline Portugal & 45 & 6 & 7 & 2 & -5 & 25 \\
\hline Romania & 165 & 35 & 21 & 9 & -12 & 144 \\
\hline Slovakia & 252 & 11 & 24 & 4 & -20 & 400 \\
\hline Slovenia & 104 & 63 & 13 & 16 & 3 & 9 \\
\hline Spain & 156 & 46 & 20 & 11 & -9 & 81 \\
\hline Sweden & 146 & 235 & 19 & 24,5 & 5,5 & 30,25 \\
\hline United Kingdom & 128 & 65 & 17 & 17 & 0 & 0 \\
\hline
\end{tabular}

We carried out the Spearman correlation analysis also for 2015 and 2016. Subsequently we repeated the analysis focusing only on the countries belonging to the "Ecoinnovation leaders" cluster. According to ECO Innovation Index, in 2015 and 2016 the eco innovation leader countries were Denmark, Finland, Germany, Luxembourg and Sweden; in 2017, in addition to these countries, Slovenia was also included in the cluster. Table 4-a and Table 4-b summarize the findings. 
Table 4-a: Results of Spearman correlation analysis between 2.3 and each of 2.1, 2.2, 3.1 ECO-IS indicators $(n=$ number of countries with available data pairs; $R c=$ critical value; $R s=$ Spearman's rank correlation coefficient).

\begin{tabular}{|c|c|c|c|}
\hline & 2.3 vs 2.1 & 2.3 vs 2.2 & 2.3 vs 3.1 \\
\hline 2015 & $\begin{array}{l}\mathrm{n}=20 \\
\mathrm{Rc}=0.38 \\
\mathrm{Rs}=-0.021 \\
\mathrm{Rs} \text { not significant at } \\
95 \% \text { prob. level }\end{array}$ & $\begin{array}{l}\mathrm{n}=20 \\
\mathrm{Rc}=0.38 \\
\mathrm{Rs}=-0.183 \\
\mathrm{Rs} \text { not significant at } \\
95 \% \text { prob. level }\end{array}$ & $\begin{array}{l}\mathrm{n}=27 \\
\mathrm{Rc}=0.324 \\
\mathrm{Rs}=-0.033 \\
\text { Rs not significant at } \\
95 \% \text { prob. level }\end{array}$ \\
\hline 2016 & $\begin{array}{l}n=20 \\
R c=0.38 \\
R s=-0.361 \\
\text { Rs not significant at } \\
95 \% \text { prob. level }\end{array}$ & $\begin{array}{l}n=20 \\
R c=0.38 \\
R s=-0.365 \\
\text { Rs not significant at } \\
95 \% \text { prob. level }\end{array}$ & $\begin{array}{l}\mathrm{n}=25 \\
\mathrm{Rc}=0.337 \\
\mathrm{Rs}=-0.244 \\
\mathrm{Rs} \text { not significant at } \\
95 \% \text { prob. level }\end{array}$ \\
\hline 2017 & $\begin{array}{l}\mathrm{n}=20 \\
\mathrm{Rc}=0.38 \\
\mathrm{Rs}=-0.272 \\
\mathrm{Rs} \text { not significant at } \\
95 \% \text { prob. level }\end{array}$ & $\begin{array}{l}\mathrm{n}=20 \\
\mathrm{Rc}=0.38 \\
\mathrm{Rs}=-0.246 \\
\mathrm{Rs} \text { not significant at } \\
95 \% \text { prob. level }\end{array}$ & $\begin{array}{l}n=25 \\
R c=0.337 \\
R s=-0.256 \\
\text { Rs not significant at } \\
95 \% \text { prob. level }\end{array}$ \\
\hline
\end{tabular}

Table 4-b: "Eco-innovation leaders" cluster - results of Spearman correlation analysis between the ECO-IS indicators 2.3 and each of 2.1, 2.2 and 3.1 ECO-IS indicators ( $\mathrm{n}=$ number of countries with available data pairs; $\mathrm{Rc}=$ critical value; $\mathrm{Rs}=$ Spearman's rank correlation coefficient).

\begin{tabular}{|c|c|c|c|}
\hline & 2.3 vs 2.1 & 2.3 vs 2.2 & 2.3 vs 3.1 \\
\hline 2015 & $\begin{array}{l}\mathrm{n}=4 \\
\mathrm{Rc}=1 \\
\mathrm{Rs}=-0.8 \\
\text { Rs not significant at } \\
95 \% \text { prob. level }\end{array}$ & $\begin{array}{l}\mathrm{n}=4 \\
\mathrm{Rc}=1 \\
\mathrm{Rs}=-0.8 \\
\text { Rs not significant at } \\
95 \% \text { prob. level }\end{array}$ & $\begin{array}{l}\mathrm{n}=5 \\
\mathrm{Rc}=0.9 \\
\mathrm{Rs}=-0.125 \\
\text { Rs not significant at } \\
95 \% \text { prob. level }\end{array}$ \\
\hline 2016 & $\begin{array}{l}\mathrm{n}=5 \\
\mathrm{Rc}=0.9 \\
\mathrm{Rs}=-0.4 \\
\text { Rs not significant at } \\
95 \% \text { prob. level }\end{array}$ & $\begin{array}{l}\mathrm{n}=5 \\
\mathrm{Rc}=0.9 \\
\mathrm{Rs}=0.0\end{array}$ & $\begin{array}{l}\mathrm{n}=5 \\
\mathrm{Rc}=0.9 \\
\mathrm{Rs}=-0.6 \\
\text { Rs not significant at } \\
95 \% \text { prob. level }\end{array}$ \\
\hline 2017 & $\begin{array}{l}\mathrm{n}=6 \\
\mathrm{Rc}=0.829 \\
\mathrm{Rs}=-0.5 \\
\mathrm{Rs} \text { not significant at } \\
95 \% \text { prob. level }\end{array}$ & $\begin{array}{l}\mathrm{n}=6 \\
\mathrm{Rc}=0.829 \\
\mathrm{Rs}=-0.086 \\
\mathrm{Rs} \text { not significant at } \\
95 \% \text { prob. level }\end{array}$ & $\begin{array}{l}\mathrm{n}=6 \\
\mathrm{Rc}=0.829 \\
\mathrm{Rs}=0.129 \\
\mathrm{Rs} \text { not significant at } \\
95 \% \text { prob. level }\end{array}$ \\
\hline
\end{tabular}

The findings show that for the years 2015-2016-2017 there is no significant correlation between the number of ISO 14001 certified organizations (ECO-IS indicator 2.3) and 
the number of enterprises that introduced an innovation with environmental benefits obtained within the firm (ECO-IS indicator 2.1). We obtain the same result by considering the number of enterprises that introduced an innovation with environmental benefits obtained by the end user (ECO-IS indicator 2.2) and the number eco-innovation related patents (ECO-IS indicator 3.1).

By considering the ECO-IS indicators 2.1, 2.2 and 3.1 as a proxy for the companies' ecoinnovation activities and results, findings suggest that for the years under analysis, the number of ISO 14001 certifications is not significantly related to eco innovation performance.

\section{Discussion and conclusions}

Given the importance of complying with the ISO 14001 standard as an essential factor for companies that want to reduce the impact of their activities on the environment, both scientists and professionals in many countries have already investigated the pros and cons of adopting EMSs (Campos, 2016). EMSs and particularly ISO 14001 certified EMS are important instruments to underpin governments' environmental policies and sustainable business strategies of enterprises (Mazzi et al., 2016). Some authors argue that adopting environmental certification practices, such as ISO 14001 certification, represents a crucial first step for the introduction of pro-active environmental practices. Indeed, these practices represent a source of change leading to internal and significant effects that boost eco-innovation (Azzone \& Noci, 1998; Bossle et al., 2016). However, the correlation between environmental performance and ISO 14001 certification primarily relies on the experience and effective implementation of improvement actions (Lannelongue et al., 2015), and it can be affected by the difficulty of understanding the crucial factors for an effective realization of EMS requirements (Mazzi et al., 2016).

Analysis of ECO-IS data in the years 2015-2016-2017 reveals that the number of ISO 14001 registered organizations (ECO-IS indicator 2.1) is not significantly related to key eco-innovation performance such as the percentage of enterprises that introduced an innovation with environmental benefits obtained within the firm (ECO-IS indicator 2.1), the percentage of enterprises that introduced an innovation with environmental benefits obtained by the end user (ECO-IS indicator 2.2) and the number of eco-innovation related patents (ECO-IS indicator 3.1). Thus, this indicator is not completely useful to understand and assess eco-innovation patterns in EU context over time. Given the importance of measuring the progress of eco-innovation drivers in order to understand the overall trend of environmental innovation (Park et al., 2017), the present study highlights the need for a new and more effective assessment approach to understand the influence of ISO 14001 standard on eco-innovation performance.

\section{Author contributions}

The authors contributed equally and are listed in alphabetical order. 


\section{References}

Arimura, T.H., Hikibi, A., \& Katayama, H. (2008). Is a voluntary approach an effective environmental policy instrument? A case for environmental management systems. J. Environ. Econ. Manag. Vol. 55, pp. 281295.

Azzone, G., Noci, G. (1998). Seeing ecology and "green" innovations as a source of change. Journal of Organizational Change Management, Vol. 11 (2), pp. 94-111 (doi.org/10.1108/09534819810212106).

Baldwin, R., \& Cave, M. (1999). Understanding Regulation: Theory, Strategy, and Practice. Oxford: Oxford University Press.

Barla, P. (2007). ISO 14001 certification and environmental performance in Quebec's pulp and paper industry. Journal of Environmental Economics and Management, Vol. 53(3), pp.291-306 (doi: 10.1016/j.jeem.2006.10.004).

Boiral, O. (2007). Corporate greening through ISO 14001: a rational myth? Organization Science, Vol. 18 (1), pp. 127-146.

Bossle, M. B., de Barcellos, M. D., Vieira, L. M., \& Sauvée, L. (2016). The drivers for adoption of ecoinnovation. Journal of Cleaner Production, Vol. 113(1), pp. 861-872. (doi.org/10.1016/j.jclepro.2015.11.033).

Campos, L.M.S. (2016). Environmental management systems (EMS) for small companies: a study in Southern Brazil. Journal of Cleaner Production, Vol. 32, pp. 141-148.

Curkovic, S., \& Sroufe, R. (2011). Using ISO 14001 to Promote a Sustainable Supply Chain Strategy. Business Strategy and the Environment, Vol. 20, pp. 71-93 (doi: 10.1002/bse.671).

Darnall, N. (2006). Why firms mandate ISO 14001 certification. Business and Society, Vol. 45 (3), 354-381.

Darnall, N., \& Edwards, D. (2006). Predicting the cost of environmental management system adoption: The role of capabilities, resources and ownership structure. Strategic Management Journal, Vol. 27(4), pp. 301320. (doi.org/10.1002/smj.518).

Decision No 1639/2006/EC of the European Parliament and of the Council. Establishing a Competitiveness and Innovation Framework Programme (2007 to 2013). Official Journal of the European Union, Vol. 310, pp. 15-40.

Dewing, I.P., \& Russell, P.O. (2004). Regulation of UK Corporate Governance: Lessons from Accounting, Audit and Financial Services. Corporate Governance: An International Review. Vol. 12 No. 1, pp. 107-115.

Doran, J., \& Ryan, G. (2012). Regulation and firm perception, eco- innovation and firm performance. European Journal of Innovation Management, Vol. 15 Issue: 4, pp.421-441. (doi.org/10.1108/14601061211272367).

Ferrón Vílchez, V. (2017). The Dark Side Of ISO 14001: The Symbolic Environmental Behavior. European Research on Management and Business Economics, Vol. 23(1), pp. 33-39.

Gautheir, T.D. (2001). Detecting Trends Using Spearman's Rank Correlation Coefficient. Environmental Forensics, Vol. 2:4, pp. 359-362. (doi:10.1080/713848278).

Giljum, S., Lieber, M., Gözet, B., \& Doranova, A. (2018-a). The Eco-Innovation Index: 2017 Version Technical Note. Available online: https://ec.europa.eu/environment/ecoap/sites/ecoap_stayconnected/files/eco innovation_index_eu_2017_technical_note.pdf (accessed on March 2019).

Giljum, S., Gözet, B., \& Doranova, A. (2018-b). The Eco-Innovation Index: 2017 EIO Brief. Available online: https://ec.europa.eu/environment/ecoap/sites/ecoap_stayconnected/files/eio brief_eu_eco innovation index 2017 final.pdf (accessed on March 2019).

Heras-Saizarbitoria, I., Arana, G., \& Boiral, O. (2015). Exploring the dissemination of environmental certifications in high and low polluting industries. Journal of cleaner production, Vol. 89, pp. 50-58. (doi: 10.1016/j.jclepro.2014.10.088).

Hojnik, J., \& Ruzzier., M. (2016). What drives eco-innovation? A review of an emerging literature. Environmental Innovation and Societal Transitions, Vol.19, pp. 31-41.

Horbach, J. (2008). Determinants of environmental innovation - new evidence from German panel data sources. Research Policy, Vol. 37, pp.163-173.

Horbach, J., Rammer, C., \& Rennings, K. (2012). Determinants of Eco-innovations by Type of Environmental Impact - The Role of Regulatory Push/Pull, Technology Push and Market Pull. Ecological Economics, Vol. 78, pp. 112-122.

International Organization for Standardization (2006). ISO 14001:2004 Environmental Management Systems Requirements with Guidance for Use. ISO, Geneva. 
ISO, (2015). Environmental Management Systems e Requirements with Guidance of Use (ISO 14001:2015). International Standard Organization, Geneva.

ISO, (2017). ISO Survey 2017. www.iso.org/iso/iso-survey (Accessed 20 January 2019).

Kammerer, D. (2009). The Effects of Customer Benefit and Regulation on Environmental Product Innovation: Empirical Evidence from Appliance Manufacturers in Germany. Ecological Economics, Vol. 68 No. 8-9, pp. 2285-2295.

Kemp, R. (2000). Technology and Environmental Policy: Innovation Effects of Past Policies and Suggestions for Improvement. Innovation and the Environment, OECD, Paris, pp 35-61.

Kesidou, E., \& Demirel, P. (2012) On the drivers of eco-innovations: empirical evidence from the UK. Research Policy, Vol. 41 (5), pp. 862-870. (doi:10.1016/j.respol.2012.01.005).

Kollman, K., \& Prakash, A. (2002). EMS-based Environmental Regimes as Club Goods. Policy Sciences, Vol. 35 No. 1, pp. $43-67$.

Lannelongue, G., Gonzales-Benito, J., Gonzales-Benito, O., Gonzales-Zapater, C., (2015). Time compression diseconomies in environmental management: the effect of assimilation on environmental performance. J. Environ. Manag, Vol. 147, pp. 203-212.

Li, X., \& Hamblin, D. (2016). Factors impacting on cleaner production: case studies in Chinese pharmaceutical manufacturers in Tianjin, China. Journal of Cleaner Production, Vol. 131, pp. 121-132. (dx.doi.org/10.1016/j.jclepro.2016.05.066).

Marin, G., Marzucchi, A., \& Zoboli, R. (2015). SMEs and barriers to eco-innovation in the EU: exploring different firm profiles. Journal of Evolutionary Economics, Vol. 25 (3), pp. 671-705. ISSN 0936-9937.

Mazzi, A., Toniolo, S., Mason, M., Aguiari, F., \& Scipioni, A. (2016) What are the benefits and difficulties in adopting an environmental management system? The opinion of Italian organizations. Journal of Cleaner Production, Vol. 139, pp. 873-885 (ㅁoi.org/10.1016/i.jclepro.2016.08.053).

Montalvo, C. (2008). General wisdom concerning the factors affecting the adoption of cleaner technologies: a survey 1990-2007. Journal of Cleaner Production, Vol. 16, pp. S7-S13.

OECD (2005). Oslo Manual. Guidelines for Collecting and Interpreting Innovation Data, third ed. OECD Publishing, Paris.

Oliveira J.A., Oliveira, O.J., Ometto A.R., Ferraudo A.S., \& Salgado M.H. (2016). Environmental Management System ISO 14001 factors for promoting the adoption of Cleaner Production practices. Journal of Cleaner Production, Vol. 133 pp. 1384-1394. (doi.org/10.1016/j.jclepro.2016.06.013).

Park, M. S., Bleischwitz, R., Han, K. J., Jang, E. K. \& Joo, J. H. (2017). Eco-Innovation Indices as Tool for Measuring Eco-Innovation. Sustainability, Vol. 9, 2206. (doi.org/10.3390/su9122206).

Porter, M., \& van der Linde, C. (1995). Toward a New Conception of the Environment Competitiveness Relationship. The Journal of Economic Perspectives, Vol. 9 No. 4, pp. 97-118.

Prajogo, D.I., Tang, A.W., \& Lai, K. (2012). Do firms get what they want from ISO 14001 adoption?: an Australian perspective. Journal of Cleaner Production, Vol. 33, pp. 117-126.

Rehfeld, K.M., Rennings, K., \& Ziegler, A. (2007). Integrated Product Policy and Environmental Product Innovations: An Empirical Analysis, Ecological Economics, Vol. 61 No. 1, pp. 91-100.

Rennings, K. (2000). Redefining innovation-eco-innovation research and the contribution from ecological economics. Ecol. Econ. Vol. 32 (2), pp. 319-332.

Rondinelli, D., \& Vastag, G., (2000). Panacea, common sense, or just a label? The value of ISO 14001 environmental management systems. European Management Journal, Vol. 18 (5), pp. 499-510.

Salim, H. K, Padfield, R., Hansen, S. Balle, Mohamad, S. Eva, Yuzir, A., Syayuti, K., Tham, M. Hou, \& Papargyropoulou, E. (2018). Global trends in environmental management system and ISO14001 research. Journal of cleaner production, Vol. 170, pp. 645-653. (doi: 10.1016/i.jclepro.2017.09.017).

Wagner, M. (2007). On the relationship between environmental management, environmental innovation and patenting: evidence from German manufacturing firms. Research Policy, Vol. 36, pp. 1587-1602. 